\title{
Effective environmental protection in the context of government decentralization
}

\section{ZhongXiang Zhang}

Published online: 16 February 2011

(C) Springer-Verlag 2011

\begin{abstract}
China has shifted control over resources and decision making to local governments and enterprises as the result of the economic reforms over the past three decades. This devolution of decision-making to local levels and enterprises has placed environmental stewardship in the hands of local officials and polluting enterprises who are more concerned with economic growth and profits than the environment. Therefore, effective environmental protection needs their full cooperation. Against this background, this paper discusses a variety of tactics that China's central government has been using to incentivize local governments, and a number of market-based instruments, supporting economic policies, environmental performance ratings and disclosure and cooperation with financial institutions to promote long-lasting, improved corporate energy-saving and environmental performance. It concludes that there is a clear need to carefully examine those objective and subjective factors that lead to the lack of local official's cooperation on the environment, and provides some suggestions for appropriated incentives to get their cooperation.
\end{abstract}

Keywords Effective environmental protection - Incentive structure $\cdot$ Economic instruments · Industrial policy · Financial institutions · Government decentralization · China

JEL classification $\mathrm{Q} 53 \cdot \mathrm{Q} 56 \cdot \mathrm{Q} 58 \cdot \mathrm{Q} 43 \cdot \mathrm{Q} 48 \cdot \mathrm{H} 23 \cdot \mathrm{H} 75 \cdot \mathrm{R} 51$

Acknowledgments An earlier version of this paper was presented at the 17th Annual Lincoln Conference on "Urban Development and the Environment in China", Cambridge, MA, 17 May 2010. It has benefited from useful discussions with the participants in the meeting and helpful comments from two anonymous referees. That said, the views expressed here are those of the author. The author bears sole responsibility for any errors and omissions that may remain.

Z. Zhang $(\bowtie)$

Research Program, East-West Center, 1601 East-West Road, Honolulu, HI 96848-1601, USA

e-mail: ZhangZ@EastWestCenter.org

\section{Z. Zhang}

Center for Energy Economics and Strategy Studies, Fudan University, Shanghai, China

\section{Z. Zhang}

China Centre for Urban and Regional Development Research, Peking University, Beijing, China 


\section{Introduction}

Confronted with the rising costs and health risks of environmental degradation associated with rapid economic growth, the central governments in Asian countries have gradually recognized that the conventional path of encouraging economic growth at the expense of the environment cannot be sustained. It has to be changed. They are convinced of the need to clean up their countries' development act. Accordingly, they set environmental goals and environmental performance requirements. Environmental ministries or equivalent agencies are empowered to take the responsibility. But they are often ill-equipped with their tasks of enforcing existing regulations and designing, implementing, monitoring, inspecting and enforcing new effective environmental polices.

The National Environmental Protection Agency of China was for years seen as a powerless entity. While the Chinese President Hu Jintao and Prime Minister Wen Jiabao gave a new lease on life and elevated it from a low vice-ministry rank, then to full ministerial status (named as the State Environmental Protection Agency (SEPA)) and currently to the Ministry of Environmental Protection (MEP) under the State Council (China's Cabinet), the MEP still does not have the authority to suspend proposed projects violating environmental laws and regulations or to remove officials who should be held accountable for this noncompliance. It also lacks the authority to manage local environmental bureaus (Zhang 2007a).

Should the MEP decide to impose a penalty on violators of EIA (environmental impact assessment) laws and regulations, as indicated in Table 1, the maximum fine at its disposal is just Yuan 200,000 (about US\$29,500). Even for environmental accidents as serious as the benzene contamination of the Songhuajiang River spill in November 2005 in Northern China, the incident that had unprecedented international implications as well as domestic social, economic and environmental ramifications, the maximum fine by China's current environmental laws is just Yuan 1 million (about US\$150,000), which was actually imposed 1 year after that incident. Moreover, the fine is only allowed to be imposed once (Zhang 2007a). As a result, this low and one-time penalty is hardly a deterrent to environmental offenders. To make things worse, even these weak punishments allowed by current environmental

Table 1 Maximum fines by category of violators of environmental laws and regulations in China

\begin{tabular}{llc}
\hline & \multicolumn{1}{c}{ Applicable laws } & $\begin{array}{c}\text { Maximum fines allowed } \\
(10000 \text { Yuan })\end{array}$ \\
\hline Exceed the pollution limit & $\begin{array}{c}\text { Atmosphere Pollution Prevention and } \\
\text { Control Act } \\
\text { Air pollution accidents }\end{array}$ & $\begin{array}{c}\text { Atmosphere Pollution Prevention and } \\
\text { Control Act }\end{array}$ \\
EIA violators, imposed only \\
$\begin{array}{l}\text { after the grace period } \\
\text { Extraordinarily environmental } \\
\text { accidents }\end{array}$ & $\begin{array}{c}\text { Environmental Impact Assessment } \\
\text { (EIA) Law }\end{array}$ & 50 \\
\hline
\end{tabular}

Source: Zhang (2008) 
laws are still weakly enforced in China because environmental protection agencies at all levels of the governments are underfunded and inadequately staffed.

As a result, poor compliance and weak enforcement are common in developing Asian countries. Correcting such a problem requires a major investment in strengthening the institutions of environmental governance to ensure that they have the adequate institutional, financial and technical capabilities to do the job. This is a necessary step, but not enough. The full participation of all stakeholders is needed in protecting the environment.

Over the past three decades, many Asian countries have decentralized in the allocation and responsibility and have shifted control over resources and decisionmaking to local governments and enterprises. This devolution of decision-making to local levels and enterprises has placed environmental stewardship in the hands of local officials and polluting enterprises. However, under the current evaluation criterion for officials in China, local officials typically have been promoted based on how fast they expand their local economies. This distorted incentive system tempts officials to disregard environmental costs of growth. Moreover, objectively speaking, the current fiscal system in China plays a part in driving local governments to seek higher GDP growth because that system makes it hard to reconcile the interests of the central and local governments (Zhang 2008 and 2010a). Since the tax-sharing system was adopted in China in 1994, taxes are grouped into taxes collected by the central government, taxes collected by local governments, and taxes shared between the central and local governments. All those taxes that have steady sources and broad bases and are easily collected, such as the consumption tax, tariffs, vehicle purchase tax, are assigned to the central government. VAT and income tax are split between the central and local governments, with $75 \%$ of VAT and $60 \%$ of income tax going to the central government. As a result, the central government revenue increased by $200 \%$ in 1994 relative to its 1993 level. This led the share of the central government in the total government revenue to go up to $55.7 \%$ in 1994 from $22.0 \%$ in the previous year (see Table 2). In the meantime, the share of the central government in the total government expenditure just rose by $2 \%$. By 2009 , local governments only accounted for $47.6 \%$ of the total government revenue, but their expenditure accounted for $80.0 \%$ of the total government expenditure in China. To enable to pay their expenditure for culture and education, supporting agricultural production, social security subsidiary, etc., local governments have little choice but to focus on local development and GDP. That in turn enabled them to enlarge their tax revenue by collecting urban maintenance and development tax, contract tax, arable land occupation tax, urban land use tax, etc.

Therefore, effective environmental protection must be placed in this context of government decentralization. In this regard, local government's cooperation is crucial to the overall outcomes. As often is the case, what the center wants is not necessarily what the center gets. An old Chinese saying goes, "The mountains are high, and the emperor is far away". Central governments need to let go of the notion that they should or even can do it all. Instead, they need to recognize that without local governments' cooperation to get these policies implemented, it is meaningless to set and defend national environmental goals, no matter how stringent they are.

Taking China as a focus and in the context of government decentralization, this paper first discusses a variety of tactics that the Chinese central government has been using to incentivize local governments. The paper then examines a number of economic policies 
Table 2 Shares of the central and local governments in the government revenue and expenditure in China, 1993-2009

\begin{tabular}{|c|c|c|c|c|}
\hline \multirow[t]{2}{*}{ Year } & \multicolumn{2}{|l|}{ Government revenue } & \multicolumn{2}{|c|}{ Government expenditure } \\
\hline & $\begin{array}{l}\text { Central government } \\
(\%)\end{array}$ & $\begin{array}{l}\text { Local governments } \\
(\%)\end{array}$ & $\begin{array}{l}\text { Central government } \\
(\%)\end{array}$ & $\begin{array}{l}\text { Local governments } \\
(\%)\end{array}$ \\
\hline 1993 & 22.0 & 78.0 & 28.3 & 71.7 \\
\hline 1994 & 55.7 & 44.3 & 30.3 & 69.7 \\
\hline 1995 & 52.2 & 47.8 & 29.2 & 70.8 \\
\hline 1996 & 49.4 & 50.6 & 27.1 & 72.9 \\
\hline 1997 & 48.9 & 51.1 & 27.4 & 72.6 \\
\hline 1998 & 49.5 & 50.5 & 28.9 & 71.1 \\
\hline 1999 & 51.1 & 48.9 & 31.5 & 68.5 \\
\hline 2000 & 52.2 & 47.8 & 34.7 & 65.3 \\
\hline 2001 & 52.4 & 47.6 & 30.5 & 69.5 \\
\hline 2002 & 55.0 & 45.0 & 30.7 & 69.3 \\
\hline 2003 & 54.6 & 45.4 & 30.1 & 69.9 \\
\hline 2004 & 54.9 & 45.1 & 27.7 & 72.3 \\
\hline 2005 & 52.3 & 47.7 & 25.9 & 74.1 \\
\hline 2006 & 52.8 & 47.2 & 24.7 & 75.3 \\
\hline 2007 & 54.1 & 45.9 & 23.0 & 77.0 \\
\hline 2008 & 53.3 & 46.7 & 21.3 & 78.7 \\
\hline 2009 & 52.4 & 47.6 & 20.0 & 80.0 \\
\hline
\end{tabular}

Source: National Bureau of Statistics of China (2010)

aimed to engage the private sector and promote its long-lasting, improved corporate energy-saving and environmental performance. Finally, it concludes that there is a clear need to carefully examine those objective and subjective factors that lead to the lack of local official's cooperation on the environment, and provides some suggestions for appropriated incentives to get their cooperation.

\section{Incentives for local governments to be more environmentally responsible}

While China has been calling for energy saving since the early 1980 s, the country has set, for the first time, the goal of cutting energy intensity by $20 \%$ in its current five-year (2006-10) economic plan. Industry accounts for about $70 \%$ of China's total energy consumption (Zhang 2003), so that this sector is crucial for China to meet its own set energy-saving goal. To that end, China established the "Top 1000 Enterprises Energy Conservation Action Program" in April 2006. This program covers 1,008 enterprises in nine key energy supply and consuming industrial subsectors. These enterprises each consumed at least 0.18 million tons of coal equivalent (tce) in 2004, and all together consumed $33 \%$ of the national total and $47 \%$ of industrial energy consumption in 2004. The National Development and Reform Commission (NDRC), China's top economic planning agency, sets energy-saving target for each of these enterprises, and 
all together these enterprises are required to achieve the overall energy saving of 100 million tce cumulatively during the period 2006-10, thus making a significant contribution to China's overall goal of $20 \%$ energy intensity-improvement (NDRC 2006a). In May 2006, empowered by the State Council (China's Cabinet), the NDRC signed energy-saving responsibility agreements with governments of 31 provinces or equivalent to allocate the overall energy-saving target of those Top 1000 enterprises in each province or equivalent. These governments in turn signed with those Top 1,000 enterprises located in their region. To ensure that the goal is met, achieving energy efficiency improvements has become a criteria for job performance evaluations of the heads of these enterprises. This will help them realize that they should take their jobs seriously because they have a very real stake in meeting energy-saving goals.

While there are areas that need further improvements (Price et al. 2010), this program goes very much as planned as far as energy saving goal is concerned. The first-year's results of its implementation show that more than $95 \%$ of these enterprises appointed energy managers, and the program achieved the energy savings of 20 million tce in 2006 (NDRC and NBS 2007). In 2007, the energy savings of 38.17 million tce were achieved, almost doubling the amount of energy savings in 2006 (NDRC 2008). The results in the first 2 years suggest that the Top 1,000 Enterprises Energy Conservation Action Program is already more than half way to meet the goal set for 2010. While China has not publicly released the results of the program's performance afterwards, the Chinese Minister of Industry and Information was quoted as saying that "those key enterprises that each consumes at least 0.18 million tce achieved the overall energy saving of 130 million tce cumulatively during the first 4 years of the 11th five-year plan period" (Liu 2010), which has been 30\% more than the cumulative goal for the program over the five-year period. This achievement has not been possible without cooperation of local governments because they have taken the responsibility for overseeing a successful implementation of those Top 1,000 enterprises in their region.

However, this high-profile Top 1,000 program should not be generalized when it comes to central-local relations. The common case is that local governments' inability, or non-cooperation, has been a major reason for the failure to meet energy efficiency and environmental goals set by the national government. The Chinese national government has implemented policies to shut down plants that are inefficient and highly polluting, and to keep the frenzied expansion of offending industries under control (Zhang 2010a, c). Local officials strongly resist, because these companies provide jobs and create tax revenues as well as personal payoffs. Forcing companies out of business could even trigger local unrest. One case in point is the differentiated tariffs. The NDRC ordered provincial governments to raise power tariffs for eight energy-guzzling industries including cement, aluminum, iron and steel, and ferroalloy from 1 October 2006 onwards. Companies classified as "eliminated types" or "restrained types" in these industries are required to pay surcharges that will increase over time, with "encouraged" and "permitted" ones charged for the normal tariffs (see Table 3). However it was reported that by mid-April 2007, not only had many local governments failed to implement the differentiated tariffs that charge more for companies in the "eliminated" or "restrained" categories, but 14 of them even continued to offer preferential power tariffs for such industries (Zhang 2007a). In fact, this is not the only time that China's provinces and regions violated this nationwide policy. Some provinces and regions have been offering preferential 
Table 3 Differentiated tariffs for eight energy-guzzling industries in China

\begin{tabular}{|c|c|c|c|c|c|}
\hline & & $\begin{array}{l}\text { Existing } \\
\text { additional } \\
\text { charge (Yuan/ } \\
\text { kWh) }\end{array}$ & $\begin{array}{l}\text { Additional charge } \\
\text { since } 1 \text { October } 2006 \\
\text { (Yuan/kWh) }\end{array}$ & $\begin{array}{l}\text { Additional } \\
\text { charge since } \\
1 \text { January } \\
2007 \text { (Yuan/ } \\
\text { kWh) }\end{array}$ & $\begin{array}{l}\text { Additional charge } \\
\text { since } 1 \text { January } 2008 \\
\text { (Yuan/kWh) }\end{array}$ \\
\hline \multirow{2}{*}{$\begin{array}{l}\text { Eight } \\
\text { energy- } \\
\text { guzzling } \\
\text { industries }\end{array}$} & $\begin{array}{l}\text { Eliminated } \\
\text { types }\end{array}$ & 0.05 & 0.10 & 0.15 & 0.20 \\
\hline & $\begin{array}{l}\text { Restrained } \\
\text { types }\end{array}$ & 0.02 & 0.03 & 0.04 & 0.05 \\
\hline
\end{tabular}

Source: NDRC (2006b)

power tariffs to struggling, local energy-intensive industries (Stanway 2009). Another case is conflicting policies on small cars between local governments and the central government (see Box 1).

Box 1 Competing interests between the central government and local governments regarding small cars Since the early 1990s, the Chinese cities have put restrictions on small vehicles, usually those with engines of less than 1.0 to 1.3 liters. Local authorities viewed small cars as slower, less reliable, more polluting and less attractive for their city's image. Some of these local concerns may have been true in the past, but are no longer legitimate because manufacturers of small cars have upgraded their safety, engines and exteriors so that they are much more reliable and energy efficient, and environmentally friendly nowadays. Concerned about the rising oil consumption and the deteriorated environment in China, the central government has been promoting reliable, energy-efficient small cars. As early as 1996, the State Council ordered to lift any kind of restrictions on small cars. But until early January 2006, it was reported that 84 cities in 22 provinces had such restrictions on small cars. These restrictions differed from one region to another, and generally speaking, took the form of limiting routes open to smaller cars, charging additional fees for license plates and/or banning the use of small cars as taxis. For example, in Beijing, cars with engines smaller than 1.0 liter had been prohibited since 1998 from driving along Changan Avenue, a main thoroughfare cross Tiananmen Square, and since 1999 from driving into the inside, fast lanes of the socalled Second Ring Road and Third Ring Road. The underlying reason was that small cars were slow to accelerate and often broke down on the road, thus exacerbating traffic jams on the city's already congested roads. In Shanghai, small cars could not use the East Yanan Road Tunnel since 2000. The city also imposes a license-plate tax of about Yuan 40,000 on private cars. Although the fee applies to all cars, it poses the biggest deterrent to potential buyers of small cars because it effectively doubles the cost of purchasing a small car. In Guangzhou, small cars with engines smaller than 1.0 liter could not even get a license plate since August 2001. In the capitals of the provinces such as Hunan, Hubei, and Shandong, cars used as taxis mandated to have engines of no less than 1.3 liters, with some even requiring engines of no less than 1.6 liters (Sina Net, 2006). On 4 January 2006, the NDRC, together with other five ministries, publicly released the enactment ordering local governments to lift all restrictions on small cars by the end of March 2006, in an effort to encourage energy conservation and environmental protection. Accordingly, local governments lifted some restrictions, if not all of them. For example, the Beijing government had lifted restrictions that prohibit small cars from driving into the inside lanes of the Second Ring Road and the Third Ring Road. Restrictions prohibiting smaller cars from driving along Changan Avenue have been partially lifted. They are now allowed to drive along the inside lane of Changan Avenue except the time from 7 am to $8 \mathrm{pm}$. The Beijing Traffic Management Bureau argued that this partial restriction is deeded necessary to avert overcrowding on the busy road which, on average, already has a traffic flow of 7,000 vehicles per hour (China Daily, 2006).

The results have also been mixed in the closure of small, inefficient coal- and oil-fired power plants and energy-inefficient and highly-polluting plants. As the largest coal consumer, power generation is currently consuming over half of the total coal used in China. This share is expected to rise well above $60 \%$ in 2020 , given the rapid 
development of coal-fired power generation (Zhang 2010c). Thus, efficient coal combustion and power generation is of paramount importance to China's endeavor of energy-saving and pollution-cutting. To that end, China has adopted the policy of accelerating the closure of thousands of small, inefficient coal- and oil-fired power plants. Units facing closure include those below $50 \mathrm{MW}$, those below $100 \mathrm{MW}$ and having in operation of over 20 years, and those below $200 \mathrm{MW}$ and having reached the end of their design life, those with a coal consumption of $10 \%$ higher than the provincial average or $15 \%$ higher than the national average, and those that fail to meet environmental standards (Zhang 2010c). The total combined capacity that needs to be decommissioned is set at $50 \mathrm{GW}$ during the period 2006-10. Relative to a total capacity of $8.3 \mathrm{GW}$ decommissioned during the period $2001-5$, by the end of the first half year of 2009, China had closed small plants with a total capacity of $54 \mathrm{GW}$, having met the 2010 target of decommissioned $50 \mathrm{GW}$ one and half years ahead of schedule (Sina Net 2009b; Zhang 2010c). By mid-July 2010, the total capacity of decommissioned smaller and older unites had increased to $70 \mathrm{GW}$, more than the entire current power capacity of the Great Britain (Yang 2010). However, China has been less successful in the areas to shut down energy-inefficient and highly-polluting plants than in the closure of small, inefficient coal- and oil-fired power plants. Following a major pollution incident in July 1994 in the Hui River, the central government launched a national campaign to close down some 72000 highly-polluting town and village industrial enterprises in 15 sub-sectors. However, some $20 \%-30 \%$ restarted, either illegally or after bringing their enterprises into compliance with relevant discharge standards (Ma and Ortolano 2000 and OECD 2001). Another case is the closure of small, inefficient and highly-polluting coal mines for environmental reasons and then the reopening of many of these plants for economic reasons. These coal mines were ordered to shut down through a widely-publicized nationwide campaign beginning in 1998. However, many had reopened because in many cases local governments had pushed back to preserve local jobs and generate tax revenues as well as personal payoffs. As a result, the coal consumption figures had been revised upwards to reflect the unreported coal production mainly from these reopened small, inefficient and highly-polluting coal mines. Table 4 shows the preliminary and final values for total primary energy consumption and coal consumption in China between 1990 and 2008. The preliminary figures for total energy use in 1999-2001 were revised upwards by $8 \%-10 \%$. In all 3 years, these adjustments were driven by upward revisions of $8 \%-13 \%$ made to the coal consumption figures.

Thus, to gain local officials' cooperation on the environmental issues, incentives need to be provided. Under the current evaluation criterion for officials in China, local officials typically have been promoted based on how fast they expand their local economies. That has created an incentive for officials to tempt to disregard the environmental costs of economic growth. To correct this distorted view of local officials' accomplishments and to implant environmental consequences in their minds, environmental performance has to be considered as well. If environmental quality does not get improved during the official's tenure, that official should not be promoted. This will help the local officials realize that they should take their jobs seriously because they have a very real stake in meeting environmental goals.

To that end, the central government of China has been using a variety of tactics to incentivize local governments (Zhang 2007b and 2008). China State Council issued 
Table 4 Preliminary and final values for total primary energy consumption and coal consumption in China, 1990-2008

\begin{tabular}{|c|c|c|c|c|c|c|}
\hline \multirow[t]{2}{*}{ Year } & \multicolumn{3}{|c|}{ Total primary energy consumption } & \multicolumn{3}{|c|}{ Total coal consumption } \\
\hline & $\begin{array}{l}\text { Preliminary value } \\
\text { (Mtce) }\end{array}$ & $\begin{array}{l}\text { Final value } \\
\text { (Mtce) }\end{array}$ & $\begin{array}{l}\text { Adjustment } \\
(\%)\end{array}$ & $\begin{array}{l}\text { Preliminary value } \\
\text { (Mtce) }\end{array}$ & $\begin{array}{l}\text { Final value } \\
\text { (Mtce) }\end{array}$ & $\begin{array}{l}\text { Adjustment } \\
(\%)\end{array}$ \\
\hline 1990 & 980.00 & 987.03 & 0.7 & 740.88 & 752.12 & 1.5 \\
\hline 1991 & 1023.00 & 1037.83 & 1.4 & 777.48 & 789.79 & 1.6 \\
\hline 1992 & 1089.00 & 1091.70 & 0.2 & 815.66 & 826.42 & 1.3 \\
\hline 1993 & 1117.68 & 1159.93 & 3.8 & 813.67 & 866.47 & 6.5 \\
\hline 1994 & 1227.37 & 1227.37 & 0.0 & 920.53 & 920.53 & 0.0 \\
\hline 1995 & 1290.00 & 1311.76 & 1.7 & 967.50 & 978.57 & 1.1 \\
\hline 1996 & 1388.11 & 1389.48 & 0.1 & 1041.08 & 1037.94 & -0.3 \\
\hline 1997 & 1420.00 & 1377.98 & -3.0 & 1043.70 & 988.01 & -5.3 \\
\hline 1998 & 1360.00 & 1322.14 & -2.8 & 973.76 & 920.21 & -5.5 \\
\hline 1999 & 1220.00 & 1338.31 & 9.7 & 818.62 & 924.77 & 13.0 \\
\hline 2000 & 1280.00 & 1385.53 & 8.2 & 857.60 & 939.39 & 9.5 \\
\hline 2001 & 1320.00 & 1431.99 & 8.5 & 884.40 & 955.14 & 8.0 \\
\hline 2002 & 1480.00 & 1517.97 & 2.6 & 978.28 & 1006.41 & 2.9 \\
\hline 2003 & 1678.00 & 1749.90 & 4.3 & 1125.94 & 1196.93 & 6.3 \\
\hline 2004 & 1970.00 & 2032.27 & 3.2 & 1333.69 & 1381.94 & 3.6 \\
\hline 2005 & 2233.19 & 2246.82 & 0.6 & 1538.67 & 1552.55 & 0.9 \\
\hline 2006 & 2462.70 & 2462.70 & 0.0 & 1709.11 & 1709.11 & 0.0 \\
\hline 2007 & 2655.83 & 2655.83 & 0.0 & 1845.80 & 1845.80 & 0.0 \\
\hline 2008 & $2850.00^{\mathrm{b}}$ & & & $1957.95^{\mathrm{b}}$ & & \\
\hline
\end{tabular}

Notes: Mtce (million tons of coal equivalent)

a National Bureau of Statistics of China is expected to adjust both preliminary and final values for energy and coal uses to make all statistics consistent, based on the second nationwide economic census. But such an adjustment in a comparable way will have little effect on a difference between their preliminary and final values

b Data on energy and coal consumption in 2008 are preliminary value

Sources: Zhang (2010d, e)

in 1982 provincial measures for collecting pollution discharge fees. The measures allow local environmental protection bureaus (EPB) to retain $20 \%$ of the fees charged for pollutants exceeding allowable standards. The fees retained, referred to as self-construction fees, can be used for environmental monitoring, research, training and awards. This may motivate local EPBs to increase monitoring and ensure compliance. However, local governments consider economic development a priority, and view the strict implementation of the over-standard fees as a severe burden on local firms, thus hampering local development. This intervention restricts effectiveness of the incentive. Moreover, the incentive itself is an issue open to question. Given their budget shortfalls as a result of the central government's call for self-supporting government agencies and local government cuts in their funding, some local EPBs, if not all, have misused this incentive as a mechanism to maximize their fee-based revenues and expand their budgets. They monitor to collect fees 
rather than ensure compliance, and reduce monitoring frequency and stop monitoring for months once a firm is determined to violate effluent standards (Ma and Ortolano 2000).

Since 1997, the SEPA (the current MEP) has run a model environmental city program. Any city, which both meets about 30 specified environmental indicators over the past three consecutive years and is among the three best performers of environmental quality in a province, is awarded the title. Out of 629 cities in China, 67 had been placed on the honor roll by the end of 2008 (MEP 2009).

To further push local governments on the environmental front, for the first time, on 13 July 2004, the SEPA unveiled its blacklist of the ten most polluted cities to discourage environmentally irresponsible decisions. That shocked local officials who had always worked on the assumption that "evil deeds" very seldom saw the light of day (Zhang 2007a, b). This public disclosure works effectively because it puts more pressure on local officials to take responsibility for the health of their people and to take action.

Since 2006, the blacklist was expanded to include cities with air quality below the class III standard designed for industrial areas. According to the evaluation on the environmental quality of Chinese 595 cities in 2006, despite four cities less than the number of those blacklisted in the previous year, there were still 39 cities on the SEPA's blacklist (SEPA 2007a). In the latest evaluation on 655 cities' environmental quality in 2009, released on 8 November 2010, the number of the cities with air quality below the class III standard went down to $8 .{ }^{1}$ Moreover, the category of blacklisted cities was further expanded to include unveiling those cities that were unable to undertake online automatic monitoring, were found to have not taken the required urban sewage treatment and to have discharged substandard waste water, and do not take proper treatment of urban garbage, etc. (MEP 2009 and 2010a). In its public release, the MEP particularly named 14 cities at the prefecture level or above because of the low levels of their groundwater quality meeting the standard, their traffic noise levels higher than the country's average, or their low scores of overall environmental infrastructure (MEP 2010a, b).

Aimed to help the general public and officials alike to understand how severely the rising environmental degradation associated with its rapid economic growth is, the SEPA and the National Bureau of Statistics of China (2006) in September 2006 jointly released the first-ever report on economic costs of pollution in 2004. Despite the shortcomings in basic data, methodologies and the coverage of items, this report estimates that the environmental pollution still costs China US\$ 64 billion, or 3.05\% of GDP in 2004. This sends a warning signal that China's rampant environmental

\footnotetext{
${ }^{1}$ China's national air quality standards for residential areas is termed the Chinese class II standards. The national standards for residential areas are set at the annual average TSP (total suspended particulate) and $\mathrm{PM}_{10}$ (particulate matter less than 10 microns in diameter) concentrations of 200 and 100 micrograms per cubic meter $\left(\mu \mathrm{g} / \mathrm{m}^{3}\right)$, respectively. In its latest evaluation of Chinese cities' environmental quality in 2009 , $78.3 \%$ of the Chinese cities were able to meet or go beyond that class II standards (MEP 2010a). That figure was only $37.6 \%$ in 2006 (SEPA 2007a). This suggests that while there is a significant progress in urban air quality, about $22 \%$ of the Chinese cities still suffer from air pollution resulting in being unable to meet the class II standards that are much lower than the WHO guidelines of $90 \mu \mathrm{g} / \mathrm{m}^{3}$ for TSP until it was abandoned for this particulate form in 2000 (The WHO (2000) abandoned the standards for this particulate form because time-series epidemiological studies were unable to define a threshold below which no health effects occur) and $20 \mu \mathrm{g} / \mathrm{m}^{3}$ for $\mathrm{PM}_{10}$.
} 
pollution problem is undermining its long-term economic growth. The SEPA is promoting to use the calculated green GDP instead of traditional GDP as the economic criterion to evaluate the real performance of local officials.

The SEPA decided in July 2006 to establish the six regional environmental protection inspection centers. Unlike local environmental protection agencies budgeted by local governments, these regional centers are directly under the leadership of the national environmental regulatory agency. Moreover, they are independent of local governments in terms of their budgets and staffs. Thus, they can confront local government's short-term intents to better represent national, long-term and general interests, have the enhanced capability to inspect and coordinate serious environmental disputes cross provincial borders and river basins, correct the distorted information on local environmental quality, and rein in the increasing local protectionists (Sina Net 2007b). This is another way to coerce cooperation between the central government and local governments as well as cooperation among local governments.

To further enhance the environmental awareness of local officials, the SEPA has tightened approval of construction projects by implementing the regional permit restrictions. The so-called regional permit restrictions are based on an ancient Chinese punishment of incriminating relatives and associates related to the main suspect. On 10 January 2007, the SEPA made an unprecedented move, suspending EIA approval of any new construction projects in four cities (Tangshan in Hebei province, Luliang in Shanxi province, Liupanshui in Guizhou province, and Laiwu in Shandong province) and four major national power-generating groups (Datang International, Huaneng Group, China Huadian Corp, and China Guodian Corp) until they bring their existing facilities into compliance with environmental regulations. Once their EIA approval rights are suspended, no new construction projects are allowed to be built in these cities and by these power-generating groups until all violators are in compliance with environmental regulations. Given that China's economy is investment-driven, local governments are fully aware of the consequences of the suspension of their right to approve new construction projects. To disregard the environmental problems in their regions now can cost them a lot (Zhang 2007a).

In fact, this is not for the first time for the SEPA to impose administrative measures to punish offenders. Since January 2005, the SEPA has unleashed a series of the so-called environmental protection storms. Its first ever such a storm unleashed on 18 January 2005, blacklisted 30 industrial projects worth Yuan 119.7 billion. Many of these projects were considered the so-called "national key projects" approved by the powerful NDRC, China's top economic planning agency. While these projects themselves were not necessarily highly polluting, the SEPA called for a halt to these industrial projects, on the ground that they had not undergone proper environmental impact assessments. This first environmental protection storm served as a public education campaign, increasing the awareness of the EIA law. In the second environmental storm in 2006, the EIA law is further strengthened, taking it from project level to the deeper level of planning. 163 proposed projects worth Yuan 774.6 billion were put on hold on enforcing EIA law alone. But, the restriction of regional permits is the strictest administrative measure ever taken by the SEPA in its 30 years of existence (Zhang 2007a, b). 
The underlying reason for suspending EIA approval rights is thought to be the desire to promote technology upgrading, industrial restructuring and sustainable development. Whether it becomes an effective means depends on how local governments and companies succeed in changing their attitudes and practices and whether local environmental protection agencies work together with the national agency. Otherwise, suspending the approval rights only has temporary effects, but does not lead to a long-term efficacy.

The new regional permit restrictions seem to be effective. Only 1 month after the restrictions suspended approval rights for the four cities, one city, Laiwu, quickly responded to the SEPA warnings and recovered its rights; and only 2 months after the suspension, Huaneng Group and China Guodian Corp, the two national powergenerating groups, came into compliance and recovered their rights (Zhang 2007a).

While there are hardly any reports on environmental protection storms in China's media since the fourth environmental protection storm unleashed in July 2007 and targeted at river basins, the MEP continues to suspend the right of those corporations and provinces to approve any new construction projects if there are any violators of environmental regulations within these corporations and provinces. For example, once the Ludila hydropower project by Huadian Power, and the Longkaikou project by Huaneng Power, both located in Lijiang, Yunnan province, were found to illegally block the river for the construction effort in January 2010 without reviewing their environmental impact, the MEP in June 2010 had ordered the country's two largest power producers to stop building the dams immediately. Moreover, the MEP suspended approval of hydropower projects along the middle reaches of Jinsha River, and suspended EIA approval of any new construction projects (except for renewable and pollution-abating projects) for the two national power-generating groups. Weifang Steel Group Corp in Shandong province started constructing a project of producing 5 million tons of steel. Given that this project violates the national industrial policy and development plan of steel industry, the MEP is suspending EIA approval of any new construction projects in the whole steel sector for the whole province (Sina Net 2009a).

China started implementing the bulletin system to release data on energy use per unit of GDP and other indicators by provincial region in 2006 (People's Daily 2005). According to the first bulletin on energy use per unit of GDP and other indicators for 2006, which was released in July 2007, among the 31 Chinese provinces or equivalent, only Beijing met energy-saving and emissions-cutting goals in 2006, cutting its energy use per unit of GDP by $5.25 \%$, followed by Tianjin, another metropolitan city in China, with the energy intensity reduction of 3.98\%, Shanghai by $3.71 \%$, Zhejiang by $3.52 \%$ and Jiangsu by $3.50 \%$ (NBS et al. 2007). In 2007, despite concerted efforts towards energy saving, the country cut its energy intensity by $4.04 \%$ (NBS et al. 2009). There are still big variations in energy-saving performance among the 31 Chinese provinces or equivalent. Beijing continued to take the lead, cutting its energy intensity by $6 \%$, followed by Tianjin by $4.9 \%$ and Shanghai by $4.66 \%$ (NBS et al. 2008). This clearly indicated Beijing's commitments to the 2008 Green Olympic Games. In the meantime, however, there were seven provinces whose energy-saving performances were below the national average. 2008 was the first year in which China exceeded the overall annualized target $(4.4 \%)$ for energy saving, cutting its energy intensity by $4.59 \%$ (NBS et al. 2009). This was due 
partly to the economic crisis that reduced overall demand, in particular the demand for energy-intensive products. Overall, the energy intensity was cut by $14.38 \%$ in the first 4 years of the plan relative to its 2005 levels (Xinhua Net 2010). In July 2010, China released its energy intensity number for 2009, and its final energy intensity numbers for the years 2005, 2006, 2007 and 2008, which are revised based on the second nationwide economic census. Based on these revised numbers, China's energy intensity fell by $15.61 \%$ from 2006 to 2009 (NBS et al. 2010). The country would meet its energy-saving goal if it could cut its energy intensity by $4.39 \%$ in 2010. However, China's energy use rose faster than its economic growth in the first half of 2010, with seven provinces becoming even more energy intensive during this period. This suggests that the country as a whole needs to accomplish the goal set for the whole year only within a half year, with some provinces required to fill even big remaining gaps during this period. Given the annual energy-saving rate of $5.25 \%$ during the period 1980-2000 in which China achieved a quadrupling of its GDP while cutting its energy intensity by about three quarters (Zhang 2003), achieving such high energy-saving rate within a half year poses a significant challenge for the country as well as for those provinces that lagged behind schedule. In this regard, local government's cooperation is crucial to the overall outcomes of cutting the energy intensity target by $20 \%$ between 2006 and 2010 relative to its 2005 level. $^{2}$ The SEPA could use its power to suspend the right to approve new construction projects in those provinces if they continue noncompliance with the energy-saving and environmental goals (Zhang 2007a).

Moreover, shifting control over resources and decision making to local governments and enterprises as the result of the economic reforms in China over the past three decades has led to insufficient investment in energy saving, with its share in the total investment in the energy industry in China declining from about $13.4 \%$ in 1983 to the level of about 3\% in 2005 (Zhang 2010a). China needs to increase investment in energy conservation and energy efficiency improvements. Faced with the prospect for the failure to meet the ambitious energy intensity target, the central government embarked additional Yuan 10 billion in mid-2007, following Yuan 11.3 billion already allocated in early that year (the total of Yuan 21.3 billion, about US\$ 3.2 billion or $4.5 \%$ of the total investment in the energy sector in 2005) specifically for energy saving, of which Yuan 9 billion to support the Ten Key Energy-saving Projects, 13 times that of the funding support in 2006 (Yuan 0.68 billion). This is a helpful step in promoting energy conservation, but the amount of fund allocated for energy saving needs to further increase. To encourage local governments to eliminate outdated production capacities, there have been repeated calls by policy experts for payment of transfer both from the central government to provincial governments in the less developed regions and from the provincial governments to those cities and counties in which a large amount of outdated production capacities have been closed down. Moreover, the amount of that transfer needs to be indexed with the real energy saving as the result of closing down the production capacities

\footnotetext{
${ }^{2}$ The reliability of both energy use and GDP data matters in meeting this energy intensity target. See Zhang $(2010 \mathrm{~d}, \mathrm{e})$ for discussions on the reliability and revisions of China's statistical data on energy and GDP, and their implications for meeting China's existing energy-saving goal in 2010 and its proposed carbon intensity target in 2020 .
} 
(Zhang 2008 and 2010a). The Chinese government has gradually recognized the importance of the payment of transfer in getting local government's cooperation. This is reflected by the central government's decision in November 2007 to transfer Yuan 2 billion to provincial governments. This is a very positive development, but this amount of payment transfer is far short of the needs. It needs to further increase, in particular given that the central government only accounts for less than $25 \%$ of the country's total government expenditure but receives over $50 \%$ of the total government revenue in China (see Table 2). The good news is that the Chinese central government has recognized these needs, increasing the amount of its fund allocated for energy saving to Yuan 41.8 billion in 2008 (including funding support for urban sewage treatment that was allocated to Yuan 4 billion in 2007) from Yuan 23.5 billion in 2007 (The State Council 2008). 2010 is the final year of China's energy efficiency drive of the 11th five-year plan, but as discussed above, China still needs to fill in the big remaining gap to meet its energy saving goal for 2010. Recognizing how challenging it is, the Chinese central government has doubled the amount of its allocated fund for energy saving relative to its level in 2008, earmarking Yuan 83.3 billion in 2010 (Xinhua Net 2010).

\section{Economic policies and engagement of the private sector}

While governments determine the rules under which businesses act, set environmental goals and commit to international environmental agreements, they count on enterprises' full cooperation. After all, the enterprises themselves are entities that make investment, use natural resources, produce products and emit pollution. In this regard, having the right economic policies is crucial because it sends clear signals to these energy consumers, helping polluting enterprises to hold accountable for their environmental behavior as well as their profits and costs. Given the widespread use of fossil fuel subsidies in developing Asian region, removing these subsidies is essential to provide incentives for efficient fuel use and adoption of clean technologies that reduce emissions at sources. By definition, a subsidy lowers the cost of production, increases the price received by producers or lowers the price paid by consumers. By lowering the prices of fossil fuels, such fossil fuel subsidies not only are widely considered to distort international trade, but also increase the amount of such fuels consumed and thus the amount of harmful emissions (Zhang and Assunção 2004). China, Indonesia and Malaysia are among the developing Asian countries that have since 2005 raised domestic energy prices to bring them more into line with international prices. This has led to sharp fall in overall energy subsidies in these countries despite rising international prices. For example, China cut its total energy subsidies to around US\$ 11 billion in 2006. This corresponds to a reduction of 58\% compared to its 2005 level of around US\$ 26 billion (IEA 2006 and 2007). China has since raised its producer prices of gasoline and diesel several times. On 1 June 2010, China increased domestic producer price of natural gas by $25 \%$ (Wan 2010). In October 2010, the NDRC was soliciting opinions nationwide regarding the two proposed options to set up tier-tariffs for household electricity use. Despite these long-awaited actions, removing such subsidies is but a first step in getting the energy prices right. Further steps to be taken include incorporating the costs of resources 
themselves to reflect their scarcity and internalizing the costs of externalities. For example, current royalties on coal resources in China are based on extraction. That is, a coal miner pays certain amount of fees for each ton of coal extracted. As a result, once a coal miner obtains mining permits, it mines recklessly. This irresponsible mining behavior is very common for small coal mines, and has led to a severe waste of coal resources, even to the destruction of coal resources. As would be expected, the coal recovery rate is reported to be only $10 \%-15 \%$ for small coal mines, implying that more than six tons of coal get wasted for each ton of coal extracted. For the country as a whole, the average recovery rate is about $30 \%,{ }^{3}$ only $60 \%$ of the advanced level abroad (He 2006). To avoid wasteful extraction and use of coal, current way in levying royalties on coal resources in China should be changed. The rational royalties on coal resources should be levied based on revenues rather than volume, indexed with both the quality of reserves and recovery rate of coal mines.

\subsection{Market-based instruments}

Market-based instruments, such as pollution charges, green taxes, tradeable petmits, and penalties for the infringement of environmental regulations, are common ways to internalize externality costs into the market prices. Many Asian countries have traditionally relied on rigid command-and-control (CAC) approaches. With the poor environmental performance of such approaches and the cost and complexity associated with their implementation, more and more countries in this region are transforming from current reliance on CAC regulations to market-based policy instruments. The added abatement costs will be imposed on polluting companies as part of production cost that can be reduced by cutting pollution. This is seen to increase not only cost-effectiveness but also flexibility in complying with the set environmental regulations.

With one-third of China's territory widely reported to be affected by acid rain, the formation of which $\mathrm{SO}_{2}$, along with $\mathrm{NO}_{2}$, contributes to, reducing $\mathrm{SO}_{2}$ emissions has been the key environmental target in China. By amending the 1987 Atmospheric Pollution Prevention and Control Act in August 1995, which newly added $\mathrm{SO}_{2}$ emissions from coal combustion as the regulated pollutant, China has since 1996 started levying the charges for $\mathrm{SO}_{2}$ emissions in the so-called Two Control Zones ${ }^{4}$ based on the total quantity of emissions and at the rate of 0.20 Yuan per kilo of pollution equivalent ( $\mathrm{Yu}$ 2006). As indicated in Table 5, since 1 July 2003, this charge was applied nationwide and the level of this charge was raised step by step. From 1 July 2005 onwards, the charge was applied at the level of 0.60 Yuan per kilo of pollution equivalent. The pollutants that are subject to pollution charges are broadened to include NOx as well, which is charged at the rate of 0.60 Yuan per kilo

\footnotetext{
${ }^{3}$ Coal recovery rates differ with scale of mines, the level of mining technologies, and type of mines. For key state-owned coal mines, the rate is $50 \%$. The corresponding figure for surface mines reaches as high as $95 \%$. But their output only accounts for $4.5 \%$ of the national total production (He 2006).

${ }^{4}$ The so-called Two Control Zones refer to acid rain control zone and $\mathrm{SO}_{2}$ control zone. The former mainly covers the southern and southwestern parts of China where precipitation is acid most of the time, whereas the latter covers the northeastern and eastern parts of the country where $\mathrm{SO}_{2}$ emissions are very intensive but the acid rain is not apparent partly because of the alkaline soils in these areas.
} 
Table 5 Levels of charges for atmospheric pollutants in China

\begin{tabular}{lll}
\hline Pollutants & Staring time & Levels of charge (Yuan/kilo pollution equivalent) \\
\hline $\mathrm{SO}_{2}$ emissions & 1 July 2003 & 0.2 \\
& 1 July 2004 & 0.4 \\
1 July 2005 & 0.6 \\
1 July 2010 & 1.2 \\
NOx emissions & 1 July 2003 & 0 \\
& 1 July 2004 & 0.6 \\
\hline
\end{tabular}

Sources: SDPC et al. (2003); The State Council (2007)

of pollution equivalent since 1 July 2004 (SDPC et al. 2003). To help to meet the energy saving and environmental control goals set for the 11 th five-year economic plan, the Chinese government plans by three steps to double the charges for $\mathrm{SO}_{2}$ emissions from the existing level to 1.2 Yuan per kilo of pollutant equivalent within the next 3 years (The State Council 2007). Local governments are allowed to raise pollution charges above the national levels. Since 1999, Beijing levied charges 1.2 Yuan per kilo of pollution equivalent for $\mathrm{SO}_{2}$ emissions from coals of high sulfur content (SDPC et al. 2003). Jiangsu province raised charges for $\mathrm{SO}_{2}$ emissions from the existing level of 0.6 to 1.2 Yuan per kilo of pollution equivalent from 1 July 2007 onwards, 3 years ahead of the national schedule (People Net 2007; Sina Net 2007a). China's Ministry of Finance, the State Administration of Taxation and the MEP have proposed for levying environmental taxes to replace current charges for $\mathrm{SO}_{2}$ emissions and chemical oxygen demand, a water pollution index. This proposal is subject to the approval of the State Council. While their exact implementation date has not been set yet, it is generally expected to be introduced during the 12th fiveyear plan period running from 2011 to 2015 . As experienced in environmental taxes in other countries (Zhang and Baranzini 2004), such taxes will initially be levied with low rates and limited scope, but their levels will increase over time. Once implemented, the long-awaited environmental taxes will have the far-reaching effects on technology upgrading, industrial restructuring and sustainable development in China.

China has been experimenting with SO2 emissions trading in Hubei, Hunan, Jiangsu, and Zhejiang provinces and Tianjin metropolitan city. Zhejiang province has implemented provincial wide trial SO2 emissions quotas that can be purchased and traded since 2009. It as well as Jiangsu is experimenting with trading COD (chemical oxygen demand) permits in Taihu Basin. In its Jinxing city, 890 enterprises were reported to participate in the paid use and trade of pollution quotas by mid-November 2009, representing rising trends of both volumes and prices of quotas transacted (CAEP 2009). Even in Shanxi province, China's coal and power base, power-generating plants sold $\mathrm{SO} 2$ emissions quotas to the State Grid. This marks that tradeable permits scheme enters the essentially operational stage in the province after years of preparation.

No doubt, economic instruments internalize the externality costs of production, and thus provide positive incentives to abate emissions. However, these economic 
instruments do not work to their full potential, although they have a solid economic foundation. In theory, cost-conscious companies will generally tolerate pollution up to the point where the expected penalty for pollution becomes greater than the cost of cutting emissions. However, the charges and fines are often set too low as have been the case in many developing countries. The average charge for urban sewage treatment was reported to be Yuan 0.7 per ton for 36 large and medium cities in China by the end of 2008, whereas the corresponding treatment cost is Yuan 1.1 per ton (NDRC 2009; CAEP 2009). Even for the aforementioned case of Jiangsu province, where the charges for $\mathrm{SO}_{2}$ emissions at 1.2 Yuan per kilo of pollution equivalent were levied from 1 July 2007 onwards, 3 years ahead of China's national schedule, this charge is still less than half of the real abatement cost, which is reported to be 3 Yuan per kilo of pollution equivalent for abating $\mathrm{SO}_{2}$ emissions from coal-fired power plants (Sina Net 2007a). As a result, many polluting companies see their compliance costs higher than the fines, and accordingly choose to pay the fines rather than to reduce their pollution. As discussed in Introduction, the low penalty is hardly a deterrent to environmental offenders in China. To change this situation, pollution charges should be raised to reflect the cost of abating pollution, and the fines for offenders should be set higher than the abatement cost. This two together will really create incentive for pollution reduction.

\subsection{Supportive economic policies}

The central government is also providing supportive economic policies to encourage technical progress and strengthen pollution control to meet the energy-saving and environmental control goals. To support the Ten Energy-saving Projects, Ministry of Finance of China and the NDRC (2007) award enterprises in East China Yuan 200, and enterprises in the Central and Western part of the country Yuan 250 for every tce saved per year since August 2007. Such payments are made to enterprises that have energy metering and measuring systems in place that can document proved energy savings of at least 10000 tce from energy-saving technical transformation projects. Moreover, in its current economic blueprint for 2006-2010, China incorporated for the first time the goal of reducing $\mathrm{SO}_{2}$ emissions by $10 \%$ by 2010 . With burning coal contributing $90 \%$ of the national total $\mathrm{SO}_{2}$ emissions and coal-fired power generation accounting for half of the national total, the Chinese central government has mandated that new coal-fired units must be synchronously equipped with a flue gas desulphurization (FGD) facility and that plants built after 1997 must have begun to be retrofitted with a FGD facility before 2010. Empowered by the State Council, the MEP (then SEPA) in May 2006 signed $\mathrm{SO}_{2}$ emissions-cutting responsibility agreements with seven provincial governments and six top national powergenerating groups, which together account for two-third of total $\mathrm{SO}_{2}$ emissions in China. And, policies favorable to FGD-equipped power plants are being implemented, e.g., the on-grid tariff incorporating desulphurization cost, priority given to be connected to grids, and being allowed to operate longer than those plants that do not install desulphurization capacity. Some provincial governments provide even more favorable policies, leading to priority dispatching of power from units with FGD in Shandong and Shanxi provinces. Moreover, the capital cost of FGD has fallen from 800 Yuan/kW in the 1990s to the level of about $200 \mathrm{Yuan} / \mathrm{kW}$ (Yu 2006), 
thus making it less costly to install FGD facility. As a result, newly installed desulphurization capacity in 2006 was greater than the combined total over the past 10 years, accounting for $30 \%$ of the total installed thermal (mostly coal-fired) capacity. This helped to slow down the growth rate of $\mathrm{SO}_{2}$ emissions significantly in 2006, which was $11.3 \%$ less than that in 2005 . By 2007, the coal-fired units installed with FGD increased to $266 \mathrm{GW}$ from $53 \mathrm{GW}$ in 2005. Generation units with FGD further rose to $379 \mathrm{GW}$ in 2008 and $470 \mathrm{GW}$ in 2009. Accordingly, the portion of coal-fired units with FGD rose to $51 \%$ in $2007,66 \%$ in 2008 and $78 \%$ in 2009 of the total installed thermal capacity from 13.5\% in 2005 (Sina Net 2009b; Zhang 2010c; Zhu 2010b). As a result, by the end of 2009, China had cut its $\mathrm{SO}_{2}$ emissions by $13.14 \%$ relative to its 2005 levels (Xinhua Net 2010), having met the 2010 target of a $10 \%$ cut 1 year ahead of schedule.

\subsection{Industrial policies}

In addition to supportive economic policies and market-based environmental instruments, governments are exploring industrial policies to promote industrial upgrading and energy conservation. With surge in energy use in heavy industry, China's Ministry of Finance and the State Administration of Taxation started levying export taxes from November 2006 on a variety of energy and resource intensive products to discourage exports of those products that rely heavily on energy and resources and to save scarce energy and resources. This includes a 5\% export tax on oil, coal and coke, a 10\% tax on to non-ferrous metals, some minerals and 27 other iron and steel products, and a $15 \%$ tax charged on copper, nickel, aluminum and other metallurgical products. Simultaneously, imports tariffs on a range of items, including 26 energy and resource products such as oil, coal and aluminum, were cut from their current levels of $3 \%-6 \%$ to $0 \%-3 \%$. From 1 July 2007 , Ministry of Finance of China and the State Administration of Taxation (2007) eliminated or cut export tax rebates for 2831 exported items. This is considered as the boldest move to rein in exports since China joined the World Trade Organization in December 2001. Among the affected items, which account for $37 \%$ of all traded products, are 553 "highly energy-consuming, highly-polluting and resource-intensive products", such as cement, fertilizer and non-ferrous metals, whose export tax rebates were completely eliminated. This policy will help to enhance energy efficiency and rationalize energy- and resource-intensive sectors as well as to control soaring exports and deflate the ballooning trade surplus. From the point of view of leveling the carbon cost playing field, such export taxes increase the price at which energyintensive products made in China, such as steel and aluminum, are traded in world markets. For the EU and U.S. producers, such export taxes imposed by their major trading partner on these products take out at least part, if not all, of the competitive pressure that is at the heart of the carbon leakage debates. Being converted into the implicit carbon costs, the estimated levels of $\mathrm{CO}_{2}$ price embedded in the Chinese export taxes on steel and aluminium are very much in the same range as the average price of the EU allowances over the same period. Zhang (2009b and 2010b) have argued that there is a clear need within a climate regime to define comparable efforts towards climate mitigation and adaptation to discipline the use of unilateral trade measures at the international level. As exemplified by export tariffs that China 
applied on its own during 2006-08, defining the comparability of climate efforts can be to China's advantage (Zhang 2010b).

Ministry of Commerce of China and the State Environmental Protection Agency (2007) in October 2007 were in an unusual collaboration to jointly issue the antipollution circular. Targeted at its booming export industry, this new regulation would suspend the rights of those enterprises that do not meet their environmental obligations to engage foreign trade in the period of more than 1 year and less than 3 years. A significant portion of China's air pollution can be traced directly to the production of goods that are exported. In the Pearl River delta, a major manufacturing region in Southern China, as indicated in Fig. 1, Streets et al. (2006) found that $37 \%$ of the total $\mathrm{SO}_{2}$ emissions in the region, $28 \%$ of $\mathrm{NO}_{x}, 24 \%$ of particulate matter (PM), and $8 \%$ of volatile organic compounds (VOCs) are caused by export-related activities. In the city of Shenzhen alone, the regional leader in industrial development and trade, $75 \%$ of VOCs, $71 \%$ of $\mathrm{PM}, 91 \%$ of $\mathrm{NO}_{x}$, and $89 \%$ of $\mathrm{SO}_{2}$ emissions from the industrial sector were released in manufacturing of exported goods. Effectively implemented, this policy will help polluting enterprises that export their products to pay attention to the environmental effects of their products and produce more environmentally friendly products.

\subsection{Environmental performance ratings and disclosure}

The central government is also exploring other ways to enhance the efficacy of environmental monitoring and compliance. Naming and shaming polluters is one vehicle. In April 2010, China's MEP for the first time unveiled offending polluters and blacklisted state-owned enterprises. ${ }^{5}$ Out of 7,043 major polluting enterprises under the national environmental monitoring system, 2,713 were found to have discharged substandard waste water or exhaust emissions in 2009, accounting for about $40 \%$ of the total monitored major polluting enterprises. The offending polluters include the state-owned China Power Investment Corp, China Huaneng Group and China Guodian Corp, the three major national power-generating groups. This fact will help change the general public's perception that it is the small, private enterprises that are the country's main sources of pollution. The listing of some sewage treatment plants was another remarkable sign in the report as $47 \%$ of 1,587 monitored waste water facilities were found guilty of substandard discharges (Deng 2010).

Governments can go beyond simple naming and shaming polluters by implementing environmental performance ratings and disclosure (PRD). The PRD, a relatively new type of instrument, rely on non-regulatory forces to create incentives for (mainly industrial) facilities to improve environmental performance. Some environmental economists call disclosure programs the third wave in pollution control policy after the first two waves that are legal regulations and market-based instruments, respectively (Tietenberg 1998). Such programs will motivate polluters to reduce emissions, even in developing countries where regulatory infrastructures

\footnotetext{
${ }^{5}$ It is reported that, according to Jairam Ramesh, India Environment Minister, India plans to launch a public database of the country's worst polluters, modeled on a list compiled by China (Hille and Lamont 2010).
} 
Fig. 1 Percentage of air pollutants tied to export manufacturing in the Pearl River Delta and Shenzhen, China. Source:

Streets et al. (2006).

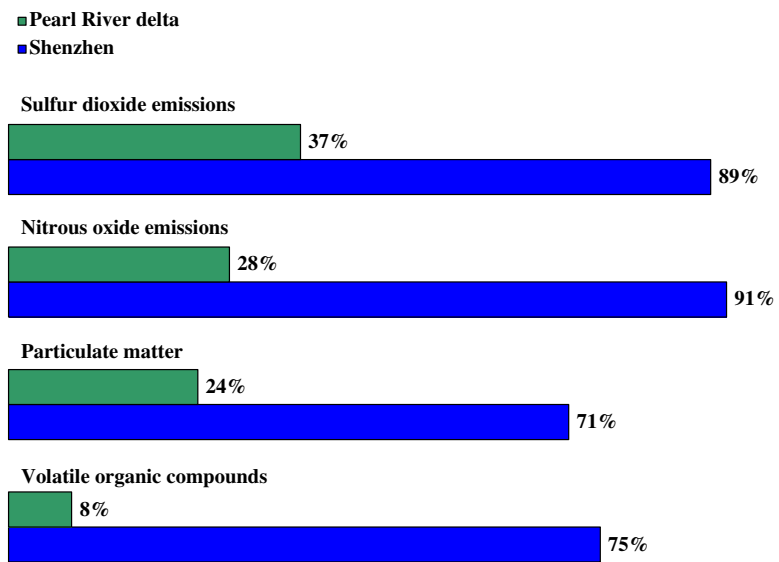

are insufficiently developed or even absent or are subjected to corruption, but where enough information can be reliably obtained to provide credible performance ratings (Dasgupta et al. 2006; World Bank 2000). Indonesia's National Pollution Control Agency (BAPEDAL) conceived and launched a program in June 1995, called PROPER - Program for Pollution Control, Evaluation and Rating, for rating and publicly disclosing the environmental performance of Indonesian factories. The PROPER develops color-coded systems to rate corporate environmental performance. The results of the initial ratings are shared with the companies rated, with those of highly environmental performance publicly congratulated. By contrast, those companies that are rated below the average category are privately notified and then given time to improve their ratings. After the grace period is over, the second rating takes place. This time, their ratings are revealed to the public in the presence of the media, officials and stakeholders. In the pilot phase of the PROPER, 187 large water polluters were rated in June 1995. 5 plants rated as GREEN (that is, very good) were publicly congratulated. The 121 firms rated as RED or BLACK, about two-thirds of the total, were privately notified of their ratings and given six-month grace period to clean up before public disclosure. One and a half years later, 5 out of the 6 plants in the worst BLACK category were upgraded to higher categories, and the number of plants rated as RED or BLACK, namely those that failed to comply with the regulations, had gone down from the two-thirds to less than half of the total. As a result, water pollution discharges from the 187 pilot plants fell by $40 \%$ (World Bank 2000). The Indonesian PROPER program has since been expanded, and its success has caught the attention of regulators in other countries.

Modeled on Indonesia's PROPER program, China introduced the Green Watch program in Zhengjiang, a relatively well-off city in Jiangsu province in June 1999, and Hohhot city, Inner Mongolia. The first Green Watch ratings were disclosed through the media in 1999. The program was extended from Zhenjiang city to all over Jiangsu province in 2001, and to eight other provinces in China during 20032005. Nationwide implementation of the Green Watch program has been promoted since 2005 (Legislative Affairs Office of the State Council of China 2007; Jin et al. 2010). Just like the Indonesian companies under the PROPER program, the companies under the Green Watch programs have dramatically changed their 
corporate environmental behavior. The Green Watch program in Jiangsu province indicates both increasing participation by firms and improvement in their compliance rates, with the number of rated firms increasing more than tenfold, from 1,059 in 2001-11,215 in 2006; and the percentage of firms with positive ratings (green, blue, and yellow) increasing from $83 \%$ in 2001 to $90 \%$ in 2006 (Table 6). Moreover, the Jiangsu case suggests that Green Watch ratings have stronger effects on firms with red ratings (moderate noncompliance) than those with black ratings (extreme noncompliance) (Legislative Affairs Office of the State Council 2007; Jin et al. 2010).

\subsection{Cooperation with financial institutions}

Drawing the support of financial institutions is another avenue to promote improved corporate environmental performance. From 1 April 2007, China's SEPA works with the People's Bank of China, China's central bank, on a new credit-evaluation system under which companies' environmental compliance records are incorporated into the bank's credit-evaluation system. This information will serve as a reference for commercial banks' consideration of whether or not to provide loans. The bank could turn down requests for loans from firms with poor environmental records (Zhang 2007a). In mid-July 2007, the SEPA announced the "green credit" policy jointly with the People's Bank of China and China Banking Regulation Commission. They will work together to enforce it, with the financial bodies denying loans to firms that the SEPA identifies as failing to meet environmental standards. The SEPA later posted on its web site and notified China's central bank and top banking regulatory

Table 6 Environmental performance ratings of the participating firms under the Green Watch program in Jiangsu province, China, 2001-2006

\begin{tabular}{lllllll}
\hline & 2001 & 2002 & 2003 & 2004 & 2005 & 2006 \\
\hline Green & 77 & 182 & 267 & 329 & 530 & 702 \\
& $(7.27)$ & $(7.26)$ & $(8.69)$ & $(6.46)$ & $(6.62)$ & $(6.26)$ \\
Blue & 512 & 1196 & 1545 & 2659 & 4016 & 5414 \\
& $(48.35)$ & $(47.69)$ & $(50.26)$ & $(52.20)$ & $(50.17)$ & $(48.27)$ \\
Yellow & 288 & 655 & 789 & 1467 & 2614 & 3944 \\
& $(27.20)$ & $(26.12)$ & $(25.67)$ & $(28.80)$ & $(32.65)$ & $(35.17)$ \\
Red & 141 & 398 & 367 & 525 & 702 & 1000 \\
& $(13.31)$ & $(15.87)$ & $(11.94)$ & $(10.31)$ & $(8.77)$ & $(8.92)$ \\
Black & 41 & 77 & 106 & 114 & 143 & 155 \\
& $(3.87)$ & $(3.07)$ & $(3.44)$ & $(2.24)$ & $(1.79)$ & $(1.38)$ \\
Total & 1059 & 2508 & 3074 & 5094 & 8005 & 11215 \\
& & & & & & \\
\hline
\end{tabular}

Note: ${ }^{1}$ Green is for superior performance; blue for full compliance; yellow for meeting major compliance standards but violating some minor requirements; red for violating important standards; and black for more extreme non-compliance

2 The dates in parentheses are percentage representation of all the participating firms in a given year Source: Legislative Affairs Office of the State Council of China (2007) 
commission 30 offending companies that will be barred from receiving credits (Xinhua Net 2007).

Some bank branches go further. Jiangyin Branch of the People's Bank of China in Jiangsu province issued the color-coded lending guidance, favoring those companies of superior environmental performance. For those green-rated companies, banks will enhance their lending scale and give priority to their financial needs. By contrast, the lending scale for those red-rated ones at best remains current level unless lending is requested for environment-improving equipments and technical transformation. Even strict lending condition is attached to those black-rated companies. They cannot receive any new borrowing, and if they still fail to comply with the environmental regulations within a given period, banks will cut their borrowing and in the worst case even they are asked to return all their borrowing (Legislative Affairs Office of the State Council of China 2007). Clearly, this concerted action by the central bank and the SEPA is expected not only to reduce the risks borne by commercial banks, but also to encourage companies to think about more about the environmental effect of their operation and self-discipline their environmental behavior. Currently, aided by the International Finance Corporation, the finance arm of the World Bank Group, China is experimenting with the green credit policy in the steel industry in Sichuan province (CAEP 2009). In August 2007, the SEPA (2007b) also clearly stipulated that highly polluting enterprises are subject to its auditing of their environmental records in case these enterprises want to list shares in the Chinese stock markets or get re-financed. China Securities Regulation Commission will incorporate information on their environmental auditing into its decision on whether or not to allow these enterprises to be listed or get refinanced.

Moreover, investors in capital markets can be an important ally, reacting to the disclosure of environmental performance related to the companies that they invest. Since 1989, the Ministry of the Environment of Korea has published the Monthly Violations Report as news material distributed to media reporters. This Report is based on information gathered through monthly government inspections on about 10,000 air and water polluting facilities, and reports the names of companies that are in violation of environmental laws and regulations and the nature of enforcement actions by the Ministry of the Environment of Korea. Since November 2000, the Report is publicly disclosed through the ministry's official web site. Over the period from 1992 to 2002, a total of 3,455 different facilities and a total of 7,073 violation events appeared on a total of 113 violation lists published on a monthly basis, implying that some appeared more than once in such lists. The econometric study using Korean company level data found that companies appearing in this monthly listing of the violators of Korean environmental laws and regulations suffered a reduction in market value of their publicly traded equities. Investors react negatively to the disclosure of such information either for moral reasons or because they believe that those offending companies will face higher clean-up costs and therefore will be less competitive. The average reduction in market value is estimated to be $9.7 \%$ (Dasgupta et al. 2006; Hong 2005). This average reduction in market value is much higher than results obtained in developed countries (Canada and the United States), but of a similar order of magnitude as results obtained in other developing countries (Argentina, Chile, Mexico and the Philippines) (Dasgupta et al. 2001). Moreover, the larger or wider the coverage of the events by newspapers, the larger the reduction in 
market value, reaching $38 \%$ for those events covered by 5 or more newspapers (Dasgupta et al. 2006; Hong 2005).

China is moving in this direction. The Shanghai Stock Exchange has disclosed environmental information since late 2009, in line with rules based on a May 2008 notice issued by the exchange to disclose corporate information (Ban 2008). The reports from companies like PetroChina and Sinopec for example are still incomplete, because they have just released discharge data, but have no mention of records of violations and the subsequent penalties (Chung 2010). Anyhow using a stock exchange as a vehicle to enhance environmental information disclosure represents the right direction. With the so-called H-shares from companies incorporated in Mainland China traded on the Hong Kong Exchanges and Clearing, it could amend its listing rules to require all those listed companies to disclose environmental information.

\section{Conclusions}

Confronted with the rising costs and health risks of environmental degradation associated with rapid economic growth, China has gradually recognized that the conventional path of encouraging economic growth at the expense of the environment cannot be sustained. It has to be changed. Accordingly, the central government sets environmental goals and environmental performance requirements. However, the environmental regulatory agency is ill-equipped either to enforce existing regulations or to design, implement, monitor, inspect and enforce new effective environmental polices to fulfill its tasks. This has led to poor compliance and weak enforcement. Correcting such a problem requires a major investment in strengthening the institutions of environmental governance to ensure that they have the adequate institutional, financial and technical capabilities to do the job. This is a necessary step, but not enough. Given that China has decentralized in the allocation and responsibility and has shifted control over resources and decision making to local governments and enterprises as the result of the economic reforms over the past three decades, the full participation of all stakeholders is also needed in protecting the environment in the context of government decentralization.

In this regard, local government's cooperation is crucial to the overall outcomes. To that end, the central government of China has been using a variety of tactics to incentivize local governments. They include placing those cities that meet the specified criteria on the honor role (the so-called model environmental city program), publicly naming the backlist of "the 10 most polluted cities" and those cities that failed to meet the specified environmental standards, having officials hold accountable for major environmental accidents, energy saving and pollution cutting in their turfs, releasing the first-ever report on economic costs of pollution (the socalled green GDP) to help the general public and officials alike to understand how severely China is confronting the rising environmental costs and health risks of environmental degradation, establishing the six regional environmental protection inspection centers independent of local governments, blacklisting those industrial projects (some even being considered the so-called "national key projects") that had not undergone proper EIAs, and suspending those local governments' rights to 
approve new projects in case there are offenders of environmental laws and regulations in their turfs.

However, under the current evaluation criterion for officials in China, local officials typically have been promoted based on how fast they expand their local economies. This distorted incentive system tempts officials to disregard environmental costs of growth. Moreover, objectively speaking, the current fiscal system in China plays a part in driving local governments to seek higher GDP growth, because under the current tax-sharing system local governments have little choice but to focus on local development and GDP in order to cover a disproportional portion of the government expenditure. Another example of the improper tax-sharing scheme in China is related to differentiated tariffs mentioned in Section 2. The NDRC ordered provincial governments to raise power tariffs for eight energy-guzzling industries from 1 October 2006 onwards, but many local governments failed to implement the differentiated tariffs that charge more for companies classified as "eliminated types" or "restrained types" in these industries, with 14 of them even continuing to offer preferential power tariffs for such industries. Partly for strengthening China's longstanding efforts to restructure its inefficient heavy industries, and partly faced with the prospect for the failure to meet the ambitious energy intensity target set for 2010, the NDRC and other 5 ministries and agencies jointly ordered utilities to stop offering preferential power tariffs to energy-intensive industries by 10 June 2010. Such industries will be charged with the punitive, differentiated tariffs. Those utilities that fail to implement the differentiated tariffs will have to pay a fine that is five times that of differentiated tariffs multiplied by the volume of sold electricity (Zhu 2010a). The reason for this failure is the lack of incentive for local governments to implement this policy, because all the revenue collected from these additional charges goes to the central government. To provide incentive for local governments, these revenue should be designed to be assigned to local governments, but the central government requires local governments to use the revenue specifically for industrial upgrading, energy saving and emissions cutting (Zhang 2008 and 2010a).

The evidence above suggests the need to carefully examine those objective and subjective factors that lead to the lack of local official's cooperation on the environment, and to provide appropriated incentives to get their cooperation. One way to ensure local officials realize that they should take their jobs seriously is developing criteria that incorporate energy conservation and environmental performance into the overall evaluation of local officials' performances. Something that will affect their promotions. To ensure the energy-saving goal to be met under the Top 1000 Enterprises Energy Conservation Action Program, achieving energy efficiency improvements has become a criteria for job performance evaluations of the heads of these enterprises. This will help them realize that they should take their jobs seriously because they have a very real stake in meeting energy-saving goals. This should be strengthened, and is extended to have local officials to hold accountable for energy saving and pollution cutting in their regions. Evaluation of local officials should abandon the unique importance of GDP. Instead, evaluation needs to look not only at economic growth of a region, but even more at the model and quality of its development. To that end, the central government not only needs to develop criteria that incorporate energy conservation and environmental performance 
into the overall evaluation of local officials' performances, more importantly applies that criteria consistently to ensure energy saving and pollution cutting in a rational way to avoid current last-minute shutdown operation of factories cross the country for meeting the energy-saving goal.

Alleviating the financial burden of local governments is another avenue to incentivize them not to eye on economic growth alone. Enlarging their tax revenue is the key to helping them cover a disproportional portion of the aforementioned government expenditure. The central government really needs to cultivate steady and sizeable sources of revenues for local governments. Enacting property taxes or real estate taxes for local governments is urgently needed. In the tax-sharing system adopted in 1994, onshore resource taxes are assigned to local governments, while the central government is collecting revenues from resource taxes off the shore. In this regard, broadening the current coverage of resource taxation and significantly increasing the levied level also help to increase local government's revenues while conserving resources and preserving the environment.

China also needs to take serious efforts towards planning and designing nationwide functional zoning. In the 11th five-year economic plan, this nationwide functional zoning concept has been sketched out. The underlying basis is that a region can be classified as optimized development zone, prioritized development zone, restrained development zone or prohibited development zone, depending on its population, resource endowment and environmental assimilating capacity. Each functional zoning is given differing development objectives. The latter are in turn aligned with different evaluation criteria for officials. For a region that needs to develop its industry, evaluation of local officials would see how fast they expand their local economies, while a region whose service sector needs to develop, evaluation would target the contribution of high-tech value added. By contrast, a region whose ecology services need to be preserved, evaluation would focus on green GDP. Planning and designing nationwide functional zoning may go beyond current administrative regions. Clearly, it is easier said than done. There has not since made much progress. But put in place and implemented effectively, a functional zoning policy not only helps to correct the current distorted incentive system, more importantly puts China towards a more sustainable development path.

The active engagement of the private sector is essential for success as well. After all, the enterprises themselves are entities that use natural resources, make products and emit pollution. Having the right economic policies is crucial for polluting enterprises to hold accountable for their environmental behavior. China needs to get rid of energy subsidies, which have been reduced over time but still exist, in order to provide incentives for efficient fuel use and adoption of clean technologies that reduce emissions at sources. But removing such subsidies is but a first step in getting the energy prices right. Further steps include incorporating the costs of resources themselves to reflect their scarcity and internalizing the costs of externalities. Currently, resource taxes in China are levied on the basis of extracted volume of resources. Starting in 1984, resource taxes have been levied at Yuan 2-5 per ton of raw coal and Yuan 8 per ton of coking coal, with the weighted average of Yuan 3.5 per ton of coal. For crude oil, the corresponding tax is levied at Yuan 8-30 per ton. 
While the prices of coal and oil have significantly increased since 1984, the levels of their resource taxes have remained unchanged over the past 25 years. As a result, the resource taxes raised amounted to only Yuan 30 billion, accounting for about $0.56 \%$ of China's total tax revenues and about $21 \%$ of the national government expenditure for environmental protection that amounted to Yuan 145 billion in 2008 (National Bureau of Statistics of China 2009). Therefore, to avoid wasteful extraction and use of resources while alleviating the financial burden of local governments, current way in levying taxes on resources in China should be changed. Such taxation should be levied based on revenues. In addition, current resource taxes are only levied on seven types of resources including coal, oil and natural gas. This coverage is too narrow, falling far short of the purposes of both preserving resources and protecting the environment. Thus, overhauling resource taxes also includes broadening their coverage so that more resources will be subject to resource taxation.

The good news is that the Chinese central government started a pilot reform on resource tax in Xinjiang, China's northwestern border area of abundant resources and numerous opportunities for growth and expansion. Since 1 June 2010, crude oil and natural gas are taxed by revenues rather than existing extracted volume in Xinjiang. While it is enacted as part of a massive support package to help Xinjiang achieve leapfrog-like development, which is considered a strategic choice to deepen the country's Western Development Strategy and tap new sources of economic growth for China, this new resource tax will help to significantly increase the revenues for Xinjiang. It is estimated that the new resource tax levied at a rate of 5\% will generate additional annual revenues of Yuan 4-5 billion for Xinjiang (Dai 2010). This is a significant increase, in comparison with the total resource tax revenues of Yuan 1.23 billion in 2009, inclusive of those from other resources than crude oil and natural gas (National Bureau of Statistics of China 2010). This will contribute to $17 \%-21 \%$ of the total tax revenues for Xinjiang, in comparison with the contribution level of about $4.1 \%$ in 2009 . The new resource tax levied on crude oil and natural gas by revenues rather than by existing extracted volume in Xinjiang since 1 June 2010 is the first step in the right direction. It needs to further broaden the coverage of resources and to be extended nationwide.

Market-based instruments, such as pollution charges, green taxes, tradeable permits, and penalties for infringing on environmental regulations, are common ways to internalize externality costs into the market prices. China has traditionally relied on rigid command-and-control approaches. With the poor environmental performance of such approaches and the cost and complexity associated with their implementation, China is increasingly implementing market-based policy instruments. The latter are seen to increase not only cost-effectiveness but also flexibility in complying with the set environmental regulations. In addition, to meet the energysaving and environmental control goals, China has provided supportive economic policies to encourage technical progress and strengthen pollution control, and has implemented policies to promote industrial upgrading and energy conservation. The country levied export taxes on energy- and resource-intensive products to discourage exports of such products that rely heavily on energy and resources and to save scarce energy and resources, eliminated or cut export tax rebates for 2831 exported items including 553 "highly energy-consuming, highly-polluting and resource-intensive 
products", and suspends the rights of those enterprises that do not meet their environmental obligations to engage foreign trade in the period of more than 1 year and less than 3 years. Naming and shaming polluters, rating and disclosing corporate environmental performance and drawing the support of financial institutions also serve as the important venues to promote long-lasting, improved corporate energysaving and environmental performance.

It should be emphasized that enacting the aforementioned policies and measures targeted for energy saving and pollution cutting just signals a goodwill and determination of China. Whether to achieve the desired outcomes depends on whether they are strictly implemented. It has been stipulated that leaders of local governments and heads of key state-owned enterprises are held accountable for energy saving and pollution cutting in their turfs, and that achieving the goals of energy efficiency improvements and pollution reductions has become a key component of their job performance evaluations. But no senior officials have been reported to take the responsibility for failing to meet the energy-saving and pollution-cutting targets, not to mention to step down from their positions on these grounds, except for the Mayor of Beijing municipality and the Governor of Shanxi province who stepped down for the mismanagement of the severe acute respiratory syndrome epidemic and ultra coal-mining accidents. Another example is the enforcement of FGD operation to ensure that those generation units with FGD facility always use it. It was reported that "up to $40 \%$ of those generation units with FGD facility did not use it" (Liu 2006). Given that FGD costs are estimated to account for about $10 \%$ of the power generation cost (Peng 2005), this should not come as a surprise, unless there is adequate enforcement. With the portion of coalfired generation capacity with FGD increasing, the government desulphurization policy should switch from mandating the installation of FGD to focusing on enforcing units with FGD to operate through on-line monitoring and control. There are encouraging signs that the Chinese government is taking steps in this direction. For example, in its 2008 assessment of the total volume reduction of major pollutants, the MEP found that FGD facilities of five coal-fired power plants were either in improper operation or their on-line monitoring and control data were false. These plants were ordered to return the compensation for their desulphurization costs in proportion to the time when their FGD facilities were not in operation and to make necessary adjustments in the specified period (Zhang 2009a).

It should be kept in mind that broad economic reforms can also help to reduce pollution and save energy. As China and many other Asian countries are based on export-oriented economies, greater openness to trade and the elimination of trade barriers between and inside countries can enhance incentives for companies to adopt more efficient and environmentally friendly technologies. As trade liberalization progresses, companies are facing ever-increasing pressures to be held accountable for their environmental behavior. Moreover, state-owned companies in this region are often heavy polluters, so decentralization and privatization to have such companies accountable for their profits and costs can contribute to cleaner production. But economic reforms are no panacea. Governments also need to anticipate and deal with potential environmental effects of such growth-promoting measures before and after they have been taken. 


\section{References}

Ban J (2008) Shanghai stock exchange requires listed companies to timely disclose environmental information, penalties being imposed on those violators. China Environmental Daily, 16 May, available at: <http://www.csfee.org.cn/ReadNews.asp?NewsID=149>

China Daily (2006) Now, small cars have the run of Changan Avenue. People's Daily Online, 3 April, available at: <http://english.people.com.cn/200604/03/eng20060403_255473.html>

Chinese Academy for Environmental Planning (CAEP) (2009) National research and pilot project on environmental economics and policy: 2009 report. Beijing, 30 December

Chung O (2010) China's listed polluters made public. Asia Times, 17 April, available at: <http://www. atimes.com/atimes/China Business/LD17Cb01.html>

Dai L (2010) Oil and gas-producing areas in Xinjiang call for the adjustment for the distribution of resource tax revenues. People Net, 29 November, available at: <http://finance.sina.com.cn/china/dfjj/ 20101129/07149023055.shtml>

Dasgupta S, Laplante B, Mamingi N (2001) Pollution and capital market in developing countries. J Environ Econ Manage 42:310-335

Dasgupta S, Wang H, Wheeler D (2006) Disclosure strategies for pollution control. In: Tietenberg T, Folmer H (eds) The international yearbook of environmental and resource economics 2006/2007: a survey of current issues. Edward Elgar, Northampton, MA, pp 93-119

Deng L (2010) MEP unveiled offending polluters: Huaneng group and other state-owned enterprises blacklisted. 21st Century Business Herald, 3 April, available at: <http://finance.sina.com.cn/g/ 20100403/05257687753.shtml>

He YG (2006) Outlook for coal industry in Mainland China. In: Zhang ZX, Bor Y (eds) Energy economics and policy in Mainland China and Taiwan. China Environmental Science Press, Beijing, pp 56-66

Hille K, Lamont J (2010) India to copy China's 'name and shame' database of worst polluters. Financial Times, 13 April

Hong JH (2005) Environmental regulatory reform and public disclosure program: Korean experience. Presented at the First Green Growth Policy Dialogue: Towards Green Growth in Asia and the Pacific: Eco-efficiency through Green Tax and Budget Reform, Seoul, 8-9 November, available at $<$ http:// www.unescap.org/esd/environment/mced/tggap/documents/RPD/19 JongHoHong.pdf>

IEA (2006) World energy outlook 2006. International Energy Agency (IEA), Paris

IEA (2007) World energy outlook 2007. International Energy Agency (IEA), Paris

Jin Y, Wang H, Wheeler D (2010) Environmental performance rating and disclosure: an empirical investigation of China's Green Watch program. Policy Research Working Paper 5420. World Bank, Washington, DC

Legislative Affairs Office of the State Council of China (2007) Work report on pilot corporate environmental performance disclosure in Jiangsu province. June, available at: <http://www.chinalaw. gov.cn/article/dfxx/dffzxx/js/200706/20070600021431.shtml>

Liu SX (2006) Why did 40\% of generation units with FGD facility not use it?. China Youth Daily, 8 August, available at: <http://zqb.cyol.com/content/2006-08/08/content_1471561.htm>

Liu JH (2010) Minister of industry and information details key targets for the industry sector during the 12th five-year plan. Xinhua Net, 9 October, available at: <http://news.sina.com.cn/c/2010-10-09/ 114321239469.shtml>

Ma X, Ortolano L (2000) Environmental regulation in China: institutions, enforcement and compliance. Rowman and Littlefield Publishers

Ministry of Commerce of China and the State Environmental Protection Agency (2007) A circular on strengthening the environmental supervision of export-engaged enterprises. Beijing, 8 October, Available at: <http://www.gov.cn/zwgk/2007-10/12/content_775030.htm>

Ministry of Environmental Protection of China (MEP) (2009) A circular on the 2008 evaluation on cities' environmental quality. Beijing, 21 December, available at: <http://www.mep.gov.cn/gkml/hbb/bgth/ 200912/t20091229_183597.htm>

Ministry of Environmental Protection of China (MEP) (2010a) 2009 Evaluation report on cities' environmental quality, Beijing, 8 November, <http:/www.gov.cn/gzdt/att/att/site1/20101105/ 001aa04b79580e3d8a6301.pdf>

Ministry of Environmental Protection of China (MEP) (2010b) MEP released the 2009 evaluation results on cities' environmental quality, Beijing, 8 November, <http://www.mep.gov.cn/gkml/hbb/qt/201011/ t20101108_197235.htm> 
Ministry of Finance of China and National Development and Reform Commission (2007) A circular on interim measures for fund management of financial incentives for energy-saving technical transformation. Beijing, 10 August, available at: <http://www.mof.gov.cn/zhengwuxinxi/ caizhengwengao/caizhengbuwengao2007/caizhengbuwengao200711/200805/t20080519_27902.html>

Ministry of Finance of China and the State Administration of Taxation (2007) A circular on lowering export tax rebates for some products. Beijing, 18 June, Available at: <http://finance.sina.com.cn/focus/ 2007tzckts/index.shtml>

National Bureau of Statistic (NBS), National Development and Reform Commission and National Energy Administration (2008) Bulletin on energy use per unit of GDP and other indicators by region. Beijing, 14 July, available at: <http://www.stats.gov.cn/tjgb/qttjgb/qgqttjgb/t20080714_402491870.htm>

National Bureau of Statistic (NBS), National Development and Reform Commission and National Energy Administration (2009) Bulletin on energy use per unit of GDP and other indicators by region. Beijing, 30 June, available at: <http://www.stats.gov.cn/tjgb/qttjgb/qgqttjgb/t20090630_402568721.htm>

National Bureau of Statistic (NBS), National Development and Reform Commission and National Energy Administration (2010) Bulletin on energy use per unit of GDP and other indicators by region. Beijing, 3 August, available at: <http://www.stats.gov.cn/tjgb/qttjgb/qgqttjgb/t20100803_402662765.htm>

National Bureau of Statistic (NBS), National Development and Reform Commission and Office of The National Energy Leading Group (2007) Bulletin on energy use per unit of GDP and other indicators by region. Beijing, 12 July, available at: <http://hzs.ndrc.gov.cn/newjn/t20070809_152873.htm>

National Bureau of Statistics of China (2009) China statistical yearbook 2009. China Statistics Press, Beijing

National Bureau of Statistics of China (2010) China statistical yearbook 2010. China Statistics Press, Beijing

National Development and Reform Commission (NDRC) (2006a) The top 1000 enterprises energy conservation action program. NDRC Environment \& Resources [2006] No.571, Beijing, 7 April, available at: <http://hzs.ndrc.gov.cn/newzwxx/t20060414_66220.htm>

National Development and Reform Commission (NDRC) (2006b) Suggestions for improving the policy on differentiated tariffs. September, available at: <http://www.gov.cn/zwgk/2006-09/22/ content_396258.htm>

National Development and Reform Commission (NDRC) (2008) A circular on the evaluation of energy saving in 2007 of the top 1000 enterprises. Beijing, 27 August, available at: <http://hzs.ndrc.gov.cn/ jnxd/t20080903 234934.htm>

National Development and Reform Commission (NDRC) (2009) Updates on recent reform on energy and resource prices. Beijing, 3 August, available at: <http://www.sdpc.gov.cn/xwfb/t20090803_294551. htm>

National Development and Reform Commission (NDRC) and National Bureau of Statistic (NBS) (2007) Bulletin on energy use of the top 1000 enterprises. Beijing, 18 September, available at: $<$ http://www. sdpc.gov.cn/zcfb/zcfbgg/2007gonggao/W020071009598162122784.pdf>

OECD (2001) Environmental priorities for China's sustainable development. CCNM/China (2001) 25. Organization for Economic Cooperation and Development (OECD), Paris

Peng JG (2005) Five top risks facing thermal power companies. China Power Enterprise Management, October

People Net (2007) Jiangsu will raise the levels of pollution charges from 1 July 2007. 11 June, available at: <http://politics.people.com.cn/GB/14562/5848072.html>

People's Daily (2005) China is going to start implementing the bulletin system to release data on energy use per unit of GDP. 17 December, available at: <http://news.sina.com.cn/c/2005-12-17/ 05457728754s.shtml>

Price L, Wang X, Yun J (2010) The challenge of reducing energy consumption of the top-1000 largest industrial enterprises in China. Energy Policy 38:6485-6498

Sina Net (2006) Special topic on small cars: when are main routes open to small cars?. Available at: $<\mathrm{http}$ ://auto.sina.com.cn/z/weixingche/index.shtml $>$

Sina Net (2007a) Jiangsu will double the charges for atmospheric pollutants from 1 July. 11 June, available at: <http://news.sina.com.cn/c/2007-06-11/012711994856s.shtml>

Sina Net (2007b) Regional environmental protection inspection system: today and future. 20 July, available at: <http://finance.sina.com.cn/economist/jingjiguancha/20070720/17203806186.shtml>

Sina Net (2009a) Ministry of environmental protection suspended approval of hydropower projects along the middle reaches of Jinsha river. 11 June, available at: <http://news.sina.com.cn/c/2009-06-11/ 112517997932.shtml> 
Sina Net (2009b) $\mathrm{SO}_{2}$ cutting goal expected to come ahead of the schedule. 7 July, available at: $<\mathrm{http}: / /$ finance.sina.com.cn/roll/20090707/04346447872.shtml>

Stanway D (2009) China blocks regional power price cuts. Reuters, 17 March, available at: <http://uk. reuters.com/article/oilRpt/idUKPEK31823420090317>

State Development and Planning Commission (SDPC), Ministry of Finance, State Environmental Protection Agency, and State Economic and Trade Commission (2003) Administrative measures on the levying levels of pollution charges. Beijing, 28 February, available at: <http://www.sepa.gov.cn/ epi-sepa/zcfg/w3/ling2003-31.htm>

State Environmental Protection Agency of China (SEPA) (2007a) SEPA released the latest evaluation on cities' environmental quality. Beijing, 11 June, available at: <http://www.sepa.gov.cn/xcjy/zwhb/ 200706/t20070611_104908.htm>

State Environmental Protection Agency of China (SEPA) (2007b) SEPA clearly stipulates highly polluting enterprises listed subject to auditing. Beijing, 19 August, Available at: <http://www.gov.cn/banshi/ 2007-08/20/content_721678.htm>

State Environmental Protection Agency of China (SEPA) and the National Bureau of Statistics (NBS) (2006) China green national accounting study report 2004: public version. Beijing, September

Streets DG, Yu C, Bergin MH, Wang X, Carmichael GR (2006) Modeling study of air pollution due to the manufacture of export goods in China's Pearl River Delta. Environ Sci Technol 40(7):2099-2107

The State Council (2007) Comprehensive work plan for energy saving and pollution cutting. Beijing, 3 June, available at: <http://news.xinhuanet.com/politics/2007-06/03/content_6191519.htm>

The State Council (2008) Work plan for energy saving and pollution cutting. Beijing, 15 July, available at: $<\mathrm{http}: / /$ www.ccchina.gov.cn/cn/NewsInfo.asp?NewsId=14127>

Tietenberg T (1998) Disclosure strategies for pollution control. Environ Resour Econ 11(3/4):587-602

Wan X (2010) Reform of natural gas price broke ground: a one-time 25\% hike. Daily Economic News, 1 June, available at: <http://finance.sina.com.cn/roll/20100601/03408034884.shtml>

World Bank (2000) Greening industry: new roles for communities, markets, and governments. Oxford University Press, New York

World Health Organization (WHO) (2000) World health organization guidelines for air quality, Geneva

Xinhua Net (2007) SEPA together with the People's Bank of China and the Baking Regulatory Commission restrict lending to highly energy-consuming and heavily polluting companies. 30 July, available at: $<\mathrm{http}: / /$ news.xinhuanet.com/newscenter/2007-07/30/content_6451563.htm>

Xinhua Net (2010) NDRC: the 11th five-year pollution-cutting goals met ahead of the schedule. 10 March, available at: <http://news.sina.com.cn/c/2010-03-10/152019834186.shtml>

Yang N (2010) China hopeful for meeting its energy-saving target. China Economic Net, 29 September, available at: <http://news.sina.com.cn/c/2010-09-29/121221194793.shtml>

Yu ZF (2006) Development and application of clean coal technology in Mainland China. In: Zhang ZX, Bor Y (eds) Energy economics and policy in Mainland China and Taiwan. China Environmental Science Press, Beijing, pp 67-88

Zhang ZX (2003) Why did the energy intensity fall in China's industrial sector in the 1990s?: the relative importance of structural change and intensity change. Energy Econ 25(6):625-638

Zhang ZX (2007a) China's reds embrace green. Far East Econ Rev 170(5):33-37

Zhang ZX (2007b) China is moving away the pattern of "develop first and then treat the pollution". Energy Policy 35:3547-3549

Zhang ZX (2008) Asian energy and environmental policy: promoting growth while preserving the environment. Energy Policy 36:3905-3924

Zhang K (2009a) Ministry of environmental protection penalizes 8 cities and 5 power plants based on the assessment of pollutant-cutting. China Business New, 24 July, available at: <http://finance.sina.com. $\mathrm{cn} / \mathrm{roll} / 20090724 / 04006522664 . \mathrm{shtml}>$

Zhang ZX (2009b) Multilateral trade measures in a post-2012 climate change regime?: what can be taken from the Montreal Protocol and the WTO? Energy Policy 37:5105-5112

Zhang ZX (2010a) Is it fair to treat China a Christmas tree to hang everybody's complaints? putting its own energy-saving into perspective. Energy Econ 32(suppl 1):S47-S56

Zhang ZX (2010b) The U.S. proposed carbon tariffs, WTO scrutiny and China's responses. Int Econ Econ Policy 7(2-3):203-225

Zhang ZX (2010c) China in the transition to a low-carbon economy. Energy Policy 38:6638-6653

Zhang ZX (2010d) Copenhagen and beyond: reflections on China's stance and responses. In: Cerdá E, Labandeira X (Eds.), Climate change policies: global challenges and future prospects. Edward Elgar, pp. $239-253$ 
Zhang ZX (2010e) Assessing China's carbon intensity pledge for 2020: stringency and credibility issues and their implications. Available at: <http://www.eastwestcenter.org/fileadmin/stored/pdfs// econwp113.pdf>

Zhang ZX, Assunção L (2004) Domestic climate policy and the WTO. World Econ 27(3):359-386

Zhang ZX, Baranzini A (2004) What do we know about carbon taxes? an inquiry into their impacts on competitiveness and distribution of income. Energy Policy 32(4):507-518

Zhu JH (2010a) Six ministries and agencies claim those utilities that fail to implement the differentiated tariffs will face a penalty equaling to five times that of supposed revenues. People Net, 22 May, available at: <http://finance.sina.com.cn/chanjing/cyxw/20100522/07037984663.shtml>

Zhu XR (2010b) China electricity council released data on fossil fuel-fired power plants in 2009. China Energy News, 19 July, available at: <http://paper.people.com.cn/zgnyb/html/2010-07/19/ content_572802.htm> 